\title{
COXEN Score 31
}

National Cancer Institute

\section{Source}

National Cancer Institute. COXEN Score 31. NCI Thesaurus. Code C128228.

A score of 31 on the COXEN Sensitivity Scale. 